\section{SOI: $1.1 /$ TAS DOI: $10.15863 / \mathrm{TAS}$ International Scientific Journal Theoretical \& Applied Science}

\author{
p-ISSN: 2308-4944 (print) e-ISSN: 2409-0085 (online) \\ Year: $2018 \quad$ Issue: $03 \quad$ Volume: 59
}

Published: $30.03 .2018 \quad$ http://T-Science.org

\begin{abstract}
Muhammad Umair Hashmi PMDC: 78548-p

Post graduate resident in Bahawal victoria Hospital Bahawalpur, Pakistan umairhashmi177@gmail.com

Laiba Khalid

PMDC: 83262-P

Doctor in Allied hospital Faisalabad, Pakistan laiba-khalid@outlook.com
\end{abstract}

Hafiza Humaira Naz PMDC: 83704-P

Doctor in Bahawal Victoria Hospital Bahawalpur,

Pakistan

hnaz794@yahoo.com

\title{
USE OF LOCKING PLATES IN DISTAL TIBIAL FRACTURE
}

Abstract: Background information: In open factures or where soft tissue is damage in distal tibia the use of Traditional external fixation method is a common treatment. It is used as a temporary or an absolute treatment. But this method has some disadvantages as its huge size and it passes over the joint. Due to these reasons use of locking plates is more suitable.

Methods \& setting: This study was done on 20 patients who presented in Bahawal Victoria Hospital Bahawalpur with fractures of distal tibia involving metaphyseal plate. Duration of study was from January 2016 to June 2017. Locking plates were used in these cases as an external fixation contrary to traditionally used external fixation methods. Follow up of these patients was done for recording time taken for union of bones and complications were observed such as non union of fracture, malunion and surgical site infections.

Results: All cases operated showed no complication of malunion, infection of plate etc. The average time for healing of fracture was 15 weeks with the range of 10-20 weeks. Plate was removed after 4 weeks of full weight bearing walk on the affected limb. The HSS score (hospital for special surgery score) was calculated. That was from 70 to 100 with mean score of 75 on first follow up (after 4 weeks), and from 80 to 100 with men score of 86 on last follow up (after 18 months). Another scoring system used was AOFAS (American orthopedic foot and ankle society) score. This score was from 88 to 100 with mean score of 90 and from 91 to 100 with mean score of 93 after 4 weeks and 18 months respectively.

Conclusion: In open type fractures of distal tibia use of locking plates is ideal due to its lighter weight than traditional external fixators and it has less complication. As this does not passes over the joint so allows early mobility in the patient and provides good range of motion at the joint.

Key words: open tibial fractures, external fixation, locking plates

Language: English

Citation: Hashmi MU, Khalid L, Naz HH (2018) USE OF LOCKING PLATES IN DISTAL TIBIAL FRACTURE. ISJ Theoretical \& Applied Science, 03 (59): 184-187.

Soi: http://s-o-i.org/1.1/TAS-03-59-31 Doi: crossef https://dx.doi.org/10.15863/TAS.2018.03.59.31

\section{INTRODUCTION}

Trauma of limbs is very common these days due to road side accidents and much common complication is fractures of limbs. Many patients report in emergency department with open fractures of distal tibia. As internal ixation has many complications so external fixation is done. ${ }^{1-3}$ Traditional technique of external fixation was used in these patients. ${ }^{4,5}$ It has some discredits that's why a new technique of external fixation by locking plates is used as a temporary or absolute treatment. ${ }^{6-11}$ In external fixation method soft tissue gets less damage. In the use of Locking plate early mobilization can be achieved with minimum post operative complications such as mal-union, non-union and deep tissue infections etc. Joint mobility can be achieved as it does not involve joint as compared to traditional fixators. This method is more safe and acceptable by the patient. Joint stiffness can be avoided. It allows rapid healing of bone and keeps fragments of bones aligned.

\section{PATIENTS AND METHODS}

This study was done on 20 patients admitted in orthopedic department of Bahawal Victoria Hospital Bahawalpur from January 2016 to June 2017. These patients had open fracture of distal tibia. In these cases locking plates were used as external fixators. 


\begin{tabular}{|c|c|c|c|c|c|c|}
\hline Impact Factor: & $\begin{array}{l}\text { ISRA (India) } \\
\text { ISI (Dubai, UAE } \\
\text { GIF (Australia) } \\
\text { JIF }\end{array}$ & $\begin{array}{r}=1.344 \\
=0.829 \\
=0.564 \\
=1.500\end{array}$ & $\begin{array}{l}\text { SIS (USA) } \\
\text { PИHЦ (Russia) } \\
\text { ESJI (KZ) } \\
\text { SJIF (Morocco) }\end{array}$ & $\begin{array}{l}=0.912 \\
=0.207 \\
=4.102 \\
=\mathbf{2 . 0 3 1}\end{array}$ & $\begin{array}{l}\text { ICV (Poland) } \\
\text { PIF (India) } \\
\text { IBI (India) }\end{array}$ & $\begin{array}{l}=6.630 \\
=1.940 \\
=4.260\end{array}$ \\
\hline
\end{tabular}

Out of 20 cases 15 were males and 5 were females with age range from 28 to 70 years and mean age of 45 years. Among these 20 study objects 2 got trauma due to fall from height and remaining 18 from roadside accidents. Open fracture was present in 14 cases and closed fracture was in 6 cases. X-ray of fracture site was done in each patient before and after operation. They were also examined on each follow up for any complication and also HSS and AOFAS scores were calculated. Operation was done under general anesthesia. Affected limb was paint and drabbed. Fracture site of tibia was reduced with either open or closed method. After reduction external plates were applied and locked with 4 to 5 screws on both ends of plate by giving small incisions on the skin. Fluoroscopy was used to check the position of implant. Patient was started to mobilize after 3 days of operation with little weight bearing in the operated limb and gradually patient was allowed to achieve full range of motion. When patient started to walk on affected limb with complete weight bearing for 6 weeks then plates were removed.

Data of patients with type of fracture according to Gustilo classification.

Table-1

\begin{tabular}{|c|c|c|c|}
\hline Number of Case & Gender & Age (years) & $\begin{array}{c}\text { Involvement of Soft } \\
\text { tissue }\end{array}$ \\
\hline 1 & F & 35 & Gustilo-1 \\
\hline 2 & M & 26 & Gustilo-2 \\
\hline 3 & M & 60 & Closed \\
\hline 4 & F & 65 & Gustilo-3a \\
\hline 5 & M & 28 & Closed \\
\hline 6 & M losed \\
\hline 7 & M & 44 & Closed \\
\hline 8 & M & 51 & Gustilo-2 \\
\hline 9 & F & 36 & Gustilo-2 \\
\hline 10 & $\mathrm{M}$ & 38 & Gustilo-1 \\
\hline 11 & $\mathrm{M}$ & 46 & Gustilo-1 \\
\hline 12 & $\mathrm{~F}$ & 70 & Gustilo-1 \\
\hline 13 & $\mathrm{M}$ & 39 & Gustilo-3a \\
\hline 14 & $\mathrm{M}$ & 29 & Gustilo-3a \\
\hline 15 & $\mathrm{~F}$ & 25 & Gustilo-1 \\
\hline 16 & $\mathrm{M}$ & 37 & Gustilo-2 \\
\hline 17 & $\mathrm{~F}$ & 64 & Gustilo-1 \\
\hline 18 & $\mathrm{M}$ & 58 & Gustilo-1 \\
\hline 19 & $\mathrm{M}$ & 41 & \\
\hline 20 & $\mathrm{M}$ & 48 & \\
\hline
\end{tabular}

\section{RESULTS}

This study was done on 20 patients reported with fracture of distal tibia. Among them 5 (25\%) were closed fractures and $15(75 \%)$ were open type of fractures. Open fractures were classified by Gustilo classification. Out of 15 open fractures $8(53.3 \%)$ were of Gustilo-1, 4(26.7\%) cases were Gustilo-2 and 3(20\%) cases had Gustilo-3A fracture. (HSS) Hospital for special surgery score range was 70-100 with mean score of 75 . Score range of (AOFAS) American orthopedic foot and ankle society was 88100 with mean score of 90 . Age of patients was from 18 to 35 years with mean age of 24 years. 


\begin{tabular}{|c|c|c|c|c|c|c|}
\hline Impact Factor: & $\begin{array}{l}\text { ISRA (India) } \\
\text { ISI (Dubai, UAE } \\
\text { GIF (Australia) } \\
\text { JIF }\end{array}$ & $\begin{array}{r}=1.344 \\
=0.829 \\
=0.564 \\
=1.500\end{array}$ & $\begin{array}{l}\text { SIS (USA) } \\
\text { PИHЦ (Russia) } \\
\text { ESJI (KZ) } \\
\text { SJIF (Morocco) }\end{array}$ & $\begin{array}{l}=0.912 \\
=0.207 \\
=4.102 \\
=2.031\end{array}$ & $\begin{array}{l}\text { ICV (Poland) } \\
\text { PIF (India) } \\
\text { IBI (India) }\end{array}$ & $\begin{array}{l}=6.630 \\
=1.940 \\
=4.260\end{array}$ \\
\hline
\end{tabular}

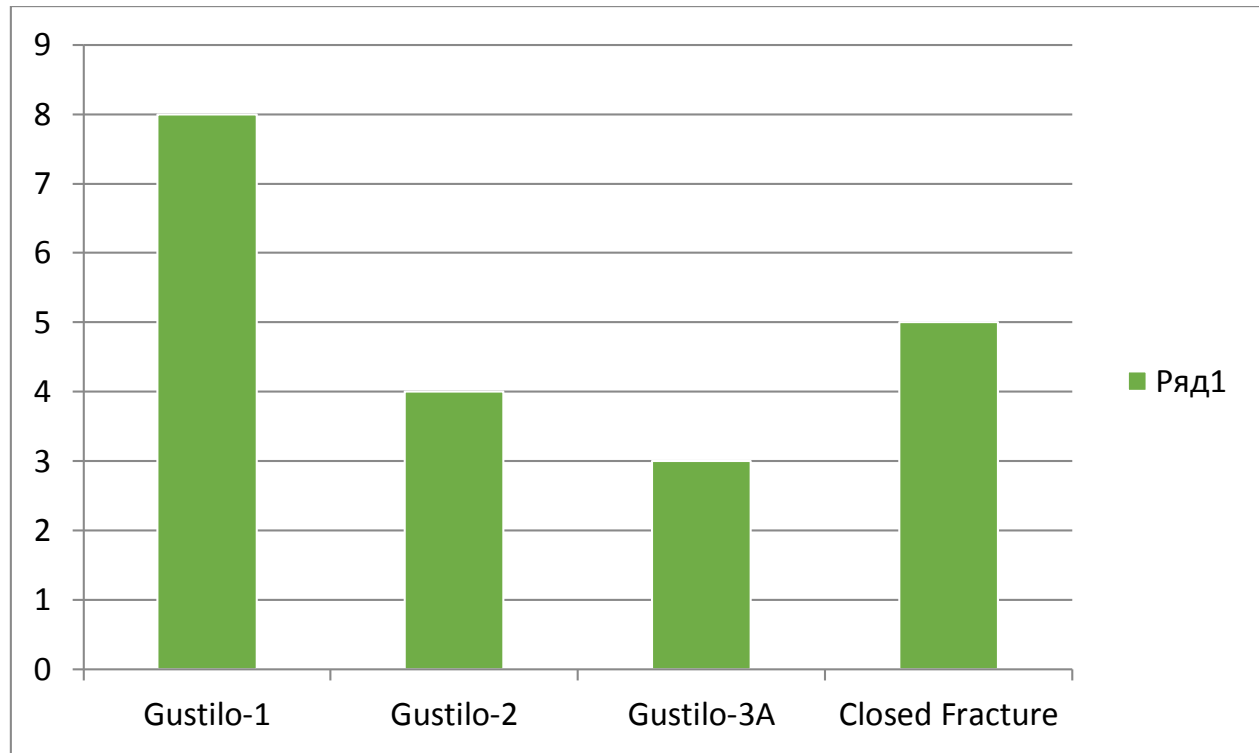

Picture 1 - Different types of distal tibial fractures and their frequencies.

\section{DISCUSSION}

This study was done to find advantages of locking plates in distal tibial fractures as compared to other traditionally used external fixators. Only those patients were included in the study which got open or closed fractures of distal tibia. Internal fixators have many disadvantages as more chances of infection and more tissue damage. While external fixation technique is safer and less tissue damage occurs.It is indicated in severe open fractures, contaminated wound, bone loss from fracture site, fractures got in war, burn wounds on fracture site etc. Traditional external fixators traverse the joint and limit its mobility and are relatively bulky. In this method there are more chances of nonunion, malunion, joint stiffness and deep infections. Before use of external fixation locking plate were considered for internal fixation. ${ }^{12}$ During the decade of 80 s few doctors used locking plates as external fixator. ${ }^{13}$ So it was found much attractive method due to less tissue damage, light weight frame, good stability and easy to apply and easy to remove. After that much advancement was done in this field to make it better. According to a study done by Kloen et al he used compression type of plates for external fixation. He used long compression plate temporary or as absolute treatment for infected fractures. He found this method economical and acceptable by the patients..$^{9,10}$ Another study done by $\mathrm{Ma}$ et al. He treated open fractures in two steps. First he applied locking plate as external fixator. When debridement of wound and coverage by soft tissue done, then he applied internal fixation by locking plates. Its results were much good. There were less complications and good stability of bone. According to our study distal tibial fractures were treated with locking plates of anatomical type as external fixator. This allowed good range of motion at the joint, early mobility and less chance of infection. Patient was able to put partial weight on the affected limb within just first week. Patients were called for follow up after 4 weeks, 2 months, 4 months and after 6, 6 months. Xrays were done on each visit. HSS score was calculated as 70-100 with average value of 75 . AOFAS score was 91-100 with average value of 93 . Final visit was done after 18 months of operation. Most of the patients underwent removal of plate after 5-6 months after walking on the affected limb for 4-6 weeks with bearing full weight. Infection of implants is very common after surgery as studied by Dillin and Slabaugh. ${ }^{15}$ They done open reduction and internal fixation in 11 cases and among them 55\% cases got surgical site infection.

\section{CONCLUSION}

Use of locking plate as an external fixator in the treatment of distal tibia fractures is better than use of traditional bulky external fixators which cause more tissue damage and more complications such as nonunion, malunion and deep infections. Externally used locking plates have much less complications and good stability of bone. This is light weight relatively and easy to apply and easy to remove. 


\begin{tabular}{l|lr|ll|ll} 
& ISRA (India) & $=\mathbf{1 . 3 4 4}$ & SIS (USA) & $=\mathbf{0 . 9 1 2}$ & ICV (Poland) & $=\mathbf{6 . 6 3 0}$ \\
Impact Factor: & ISI (Dubai, UAE) $=\mathbf{0 . 8 2 9}$ & PUHL (Russia) $=\mathbf{0 . 2 0 7}$ & PIF (India) & $=\mathbf{1 . 9 4 0}$ \\
& GIF (Australia) & $\mathbf{0 . 5 6 4}$ & ESJI (KZ) & $=\mathbf{4 . 1 0 2}$ & IBI (India) & $\mathbf{4 . 2 6 0}$ \\
& JIF & $=\mathbf{1 . 5 0 0}$ & SJIF (Morocco) & $=\mathbf{2 . 0 3 1}$ & & \\
\hline
\end{tabular}

\section{References:}

1. Mc Ferran MA, Smith SW, Boulas HJ, Schwartz HS. (1992) Complications encountered in the treatment of pilon fractures. J Orthop Trauma. 1992; 6(2): 195200[DOI] [PubMed]

2. Tejwani NC, Hak DJ, Finkemeier CG, Wolinsky PR. (2006) High-energy proximal tibial fractures: treatment options and decision making. Instr Course Lect. 2006; 55: 36779[PubMed]

3. Lau TW, Leung F, Chan CF, Chow SP. (2008) Wound complication of minimally invasive plate osteosynthesis in distal tibia fractures. Int Orthop. 2008; 32(5): 697-703

4. Sirkin M, Sanders R, DiPasquale T, Herscovici DJ. (1999) A staged protocol for soft tissue management in the treatment of complex pilon fractures. J Orthop Trauma. 1999; 13(2): 78-84

5. Tejwani NC, Achan P. (2004) Staged management of high-energy proximal tibia fractures. Bull Hosp Jt Dis. 2004; 62(1-2): 62-6

6. Ma CH, Tu YK, Yeh JH, Yang SC, Wu CH. (2011) Using external and internal locking plates in a two-stage protocol for treatment of segmental tibial fractures. J Trauma. 2011; 71(3): 614-9

7. $\mathrm{Ma} \mathrm{CH}, \mathrm{Wu} \mathrm{CH}, \mathrm{Yu} \mathrm{SW}, \mathrm{Yen} \mathrm{CY}, \mathrm{Tu} \mathrm{YK}$. (2010) Staged external and internal lessinvasive stabilisation system plating for open proximal tibial fractures. Injury. 2010; 41(2): 190-6
8. Ma CH, Yu SW, Tu YK, Yen CY, Yeh JJ, Wu CH. (2010) Staged external and internal locked plating for open distal tibial fractures. Acta Orthop. 2010; 81(3): 382-6

9. Kloen P. (2009) Supercutaneous plating: use of a locking compression plate as an external fixator. J Orthop Trauma. 2009; 23(1): 72-5

10. Tulner SA, Strackee SD, Kloen P. (2012) Metaphyseal locking compression plate as an external fixator for the distal tibia. Int Orthop. 2012; 36(9): 1923-7

11. Ma CH, Wu CH, Tu YK, Lin TS. (2013) Metaphyseal locking plate as a definitive external fixator for treating open tibial fractures--clinical outcome and a finite element study. Injury. 2013; 44(8): 1097-101

12. Tepic S. (1995) The biomechanics of the PC Fix internal fixator. Injury. 1995; 26: 5-10

13. Ramotowski W, Granowski R. (1984) Das zespol osteosynthesesystem, Mechanische grun dlage und klinische anwendung. Orthop Praxis. 1984; 9: 750-8

14. Koulouvaris P, Stafylas K, Mitsionis G, Vekris M, Mavrodontidis A, Xenakis T. (2007) Longterm results of various therapy concepts in severe pilon fractures. Arch Orthop Trauma Surg. 2007; 127(5): 313-20

15. Dillin L, Slabaugh P. (1986) Delayed wound healing, infection, and nonunion following open reduction and internal fixation of tibial plafond fractures. J Trauma. 1986; 26(12): 1116-9 